\title{
PERANCANGAN PEMBANGKIT TENAGA SURYA DENGAN PENGARAH SINAR MATAHARI OTOMATIS BERBASIS ARDUINO UNO
}

\author{
Victor Siallagan ${ }^{1)}$, Missyamsu Algusri ${ }^{2)}$ \\ ${ }^{1,2)}$ Program Studi Teknik Elektro, Fakultas Teknik, Universitas Riau Kepuluan Batam \\ E-mail: victor_siallagan@yahoo.com
}

\begin{abstract}
Sunlight energy source in solar power plants is needed in the direction of solar cells to produce greater energy energy. In use with the position of solar cells with fixed position (fixed) a fixed position to the sun produces absorption of light is not maximal. Therefore a sunlight steering is required to detect this position and as input for the controller to produce the control action of moving the solar cell reaches always perpendicular to the sun. Position angle of tilt as a common axis to move solar cells from the east (sunrise) and to the west (sunset). Comparison of systems with two different positions that generate different power to power generation of electricity generated by solar cells. Comparison of the output of solar cell specifications of $2.5 \mathrm{Watt} ; 8.2 \mathrm{VDC}$; $0.3 \mathrm{~A}$ in a still stationary position is $2.93 \mathrm{Watts}$ and an average of 0.24 Watts to the output of solar cells with a beam guide is 4.44 Watts and an average of 0.34 Watt.
\end{abstract}

Keywords : Solar cell, fixed position, Power

\begin{abstract}
ABSTRAK
Sinar matahari sumber energi pada pembangkit listrik tenaga surya sangat diperlukan searah dengan sel surya untuk menghasilkan energi listrik yang lebih besar. Pada pemakaian dengan posisi sel surya dengan posisi tetap (fixed) satu posisi tetap terhadap matahari menghasilkan serapan sinar tidak maksimal. Oleh karena itu pengarah sinar matahari diperlukan untuk mendeteksi posisi ini dan sebagai inputan bagi kontroller untuk manghasilkan aksi kontrol menggerakan sel surya mencapai selalu tegak lurus ke arah matahari. Posisi angle of tilt sebagai axis yang umum untuk menggerakkan sel surya dari arah timur (matahari terbit)dan ke barat (matahari terbenam). Perbandingan sistem dengan dua posisi yang berbeda itu menghasilkan daya yang berbeda terhadap pembangkitan daya energi listrik yang dihasilkan oleh sel surya. Perbandingan keluaran sel surya spesifikasi sel surya 2.5 Watt; 8,2 VDC; 0,3 A pada posisi tetap diam adalah 2,93 Watt dan rata-rata 0.24 Watt terhadap keluaran sel surya dengan pengarah sinar adalah 4,44 Watt dan rata-rata 0.34 Watt
\end{abstract}

Kata kunci : Sel surya, posisi tetap, Daya. 


\section{PENDAHULUAN}

\subsection{Latar Belakang}

Ketergantungan terhadap sumber energi listrik yang berbahaan baku fosil untuk keberlangsungan pasokan tenaga listrik masih sangat sangat besar. Pada tahun 2000 kebutuhan energi listrik dunia mencapai 7-8 triliyun $\mathrm{KWH}$ dan diprediksikan pada tahun 2020 kebutuhan akan mencapai 14,5 triliyun $\mathrm{KWH}$, Indonesia mengeluarkan kebijakan mencanangkan target memperbesar kontribusi sumber energi terbarukan, khusus nya tenaga surya sebesar $0,2-0,3 \%$ pada tahun 2025 [1]. Diperlukan penambahan kapasitas $65 \mathrm{MW}$ per tahun yang pada aktualnya pemanfaatannya sekarang masih rendah hanya 2,5 MW per tahun masih jauh dari target [6].

Dengan realitas paparan sinar matahari berubah posisi menghasilkan tingkat intensitas sinarnya matahari yang lebih maksimal sehingga berpotensi menghasilkan listrik yang lebih besar [3]. Perancangan Pembangkit Tenaga Surya Dengan Pengarah Sinar Matahari Otomatis Berbasis Arduino Uno ini menggunakan Light Dependent Resistor (LDR) sebagai input, arduino uno sebagai kontroller dan aksi kontrol oleh servo motor mengatur kesearah-an penerimaan panel sel surya terhadap sinar matahari seiring perubahan posisi arah sudut sinar matahari.

\section{LANDASAN TEORI}

\subsection{Tinjauan Pustaka}

Pema nfaatan dari energi surya dapat dimaksimalkan dengan menjaga setiap pergerakan matahari selalu searah dengan penerima sinar matahari, melalui suatu sistem pengarah sinar matahari automatis yang mampu mendapatkan energi matahari secara penuh, yaitu dengan membuat panel surya dapat terus menghadap ke arah sumber sinar matahari [8]. Penerimaan radiasi matahari oleh sel surya dipengaruhi oleh sudut datang sinar matahari (angle of incidence).

Panel sel surya mendapat radiasi maksimum jika sinar matahari tegak lurus dengan bidang panel dan sebaliknya pada saat tidak tegak lurus akan mendapat radiasi lebih kecil seperti gambar 2.1

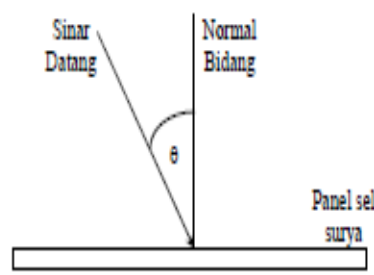

Gambar 2.1 Sudut Sinar matahari terhadap sel surya [3]

$\operatorname{Ir}=\operatorname{Iro} \operatorname{Cos} \varnothing \mathrm{T}$ $1.1[10]$

Dimana:

Ir : Radiasi yang diserap panel sel surya Iro: Radiasi yang mengenai panel sel surya ØT: Sudut panel sel surya terhadap sinar dating (sorotan)

\subsection{SensorPendeteksi Sinar}

Untuk mendeteksi adanya cahaya sinar matahari pada perancangan ini memerlukan piranti yang pada percancangan ini sensor light Dependent Resistor(LDR). Tahanannya berkurang jika mendapat paparan sinar matahari, gambar fisiknya ditunjukkan pada gambar 2.2

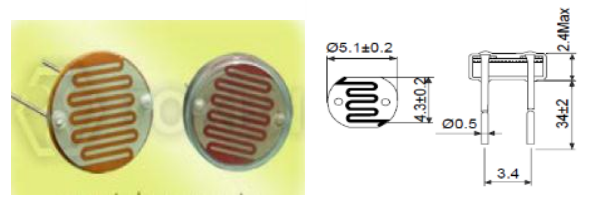

Gambar 2.2 Konstruksi LDR dan dimensi

\subsection{Kontroler Arduino Uno}

Arduino Uno adalah sebuah perangkat keras keluaran dari Arduino Italy 
yang berupa minimum system dengan menggunakan mikrokontroler Atmega 328. Untuk bentuk fisik dari Modul Mikrokontroler Arduino Uno bisa dilihat pada gambar 2.3

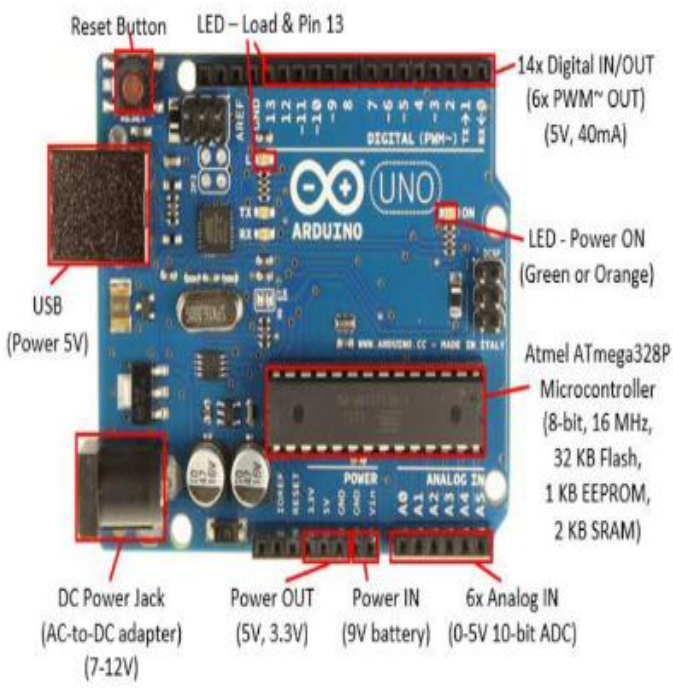

\section{Gambar 2.3 Modul Mikrokontroler Arduino Uno [4]}

Mikrokontroler Arduino Uno memiliki 14 pin digital yang diantaranya terdapat 6 pin yang dapat digunakan sebagai output Pulse Width Modulation atau PWM yaitu pin D.3, D.5, D.6, D.9, D.10, D.11 dan 6 pin input analog. Menggunakan osilator sebesar $16 \mathrm{MHz}$, koneksi USB, ICSP header dan tombol reset. Untuk konfigurasi pin Atmega 328

\subsection{Motor Servo Standard $180^{\circ}$}

Motor servo hanya memiliki 3

kabel yang mana masing-masing fungsinya terdiri dari positif (Vcc), negatif (Ground) dan kontrol (Signal). Motor servo mampu bergerak searah jarum jam ataupun berlawanan arah jarum jam tanpa membalik pin konektor pada motor servo, hal ini disebabkan bahwa pada motor servo telah terdapat driver untuk membalik polaritas motor DC yang ada pada motor servo. Motor servo jenis standar hanya dapat berputar $180^{\circ}$ searah atau berlawanan arah jarum jam.

Prinsip kerja motor servo standar adalah kaki sinyal motor servo diberi sinyal digital dengan lebar sinyal antara 0,60 milidetik sampai 2,00 milidetik.

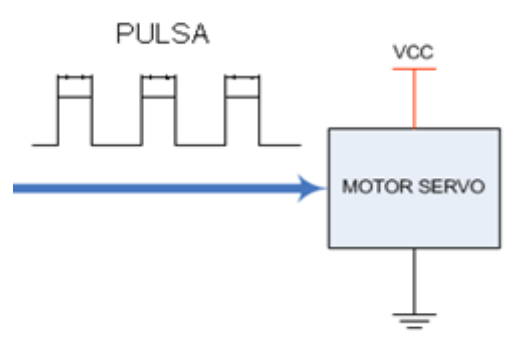

Gambar 2.4 Skematis Pengiriman Pulsa[9]

\subsection{Sel Surya (Solar Cell)}

Sel Surya atau Solar Cell adalah suatu perangkat atau komponen yang dapat mengubah energi cahaya matahari menjadi energi listrik dengan menggunakan prinsip efek Photovoltaic. Yang dimaksud dengan Efek Photovoltaic adalah suatu fenomena dimana munculnya tegangan listrik karena adanya hubungan atau kontak dua elektroda yang dihubungkan dengan sistem padatan atau cairan saat mendapatkan energi cahaya

Berikut ini adalah Struktur Dasar, Bentuk dan Simbol Sel Surya (Solar Cell).

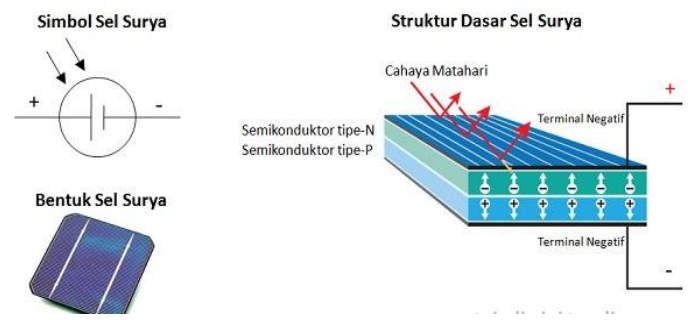




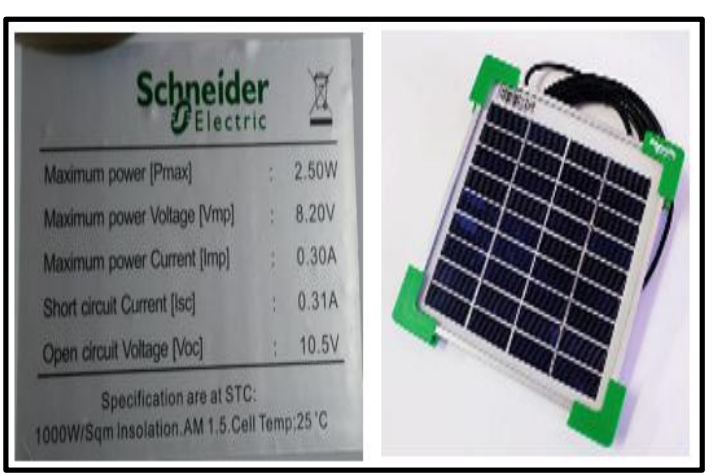

Gambar 2.5 Panel Sel Surya

Pada perancangan ini menggunakan Perangkat output Panel Sel Surya dengan spesifikasi 2,50 W ; 8,20 VDC seperti terlihat pada gambar 2.5

\subsection{Sumber Tenaga Catu Daya}

Untuk mengoperasikan rangkaian dan perangkat elektronik diperlukan sumber tenaga atau catu daya. Catu daya bias saja berupa baterai atau rangkaian catu daya. Baterai atau accu adalah sumber catu daya DC yang paling baik. Namun untuk aplikasi yang membutuhkan catu daya lebih besar, sumber dari baterai tidak cukup. Sumber catu daya yang besar adalah sumber bolak-balik AC (alternating current) dari pembangkit tenaga listrik. Untuk itu diperlukan suatu perangkat catu daya yang dapat mengubah arus $\mathrm{AC}$ menjadi DC. Catu daya yang digunakan adalah Regulator. Regulator tegangan adalah bagian power supply yang berfungsi untuk memberikan stabilitas output pada suatu power supply.

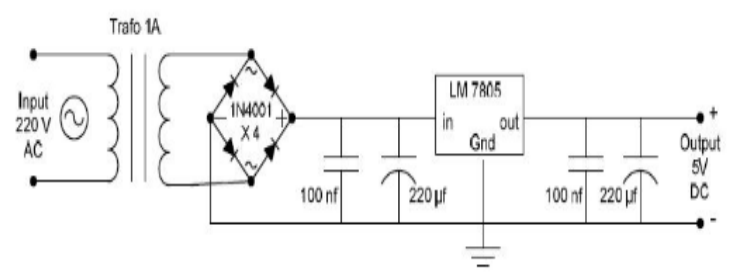

Gambar 2.6 Rangkaian catu daya menggunakan regulator [6]

\section{METODOLOGI PENELITIAN}

Bab ini menjelaskan perancangan sistem pembangkit listrik tenaga surya dengan posisi sel surya sensor tetap diam dengan posisi sel surya bergerak dengan sensor pengarah ke sinar matahari.Adapun metodologi penelitian adalah sebagai berikut:

\subsection{Alir Penelitian}

Alir Penelitian yang digunakan untuk membuat alat perancangan ini mengunakan metode bangun, seperti diagram alir berikut :

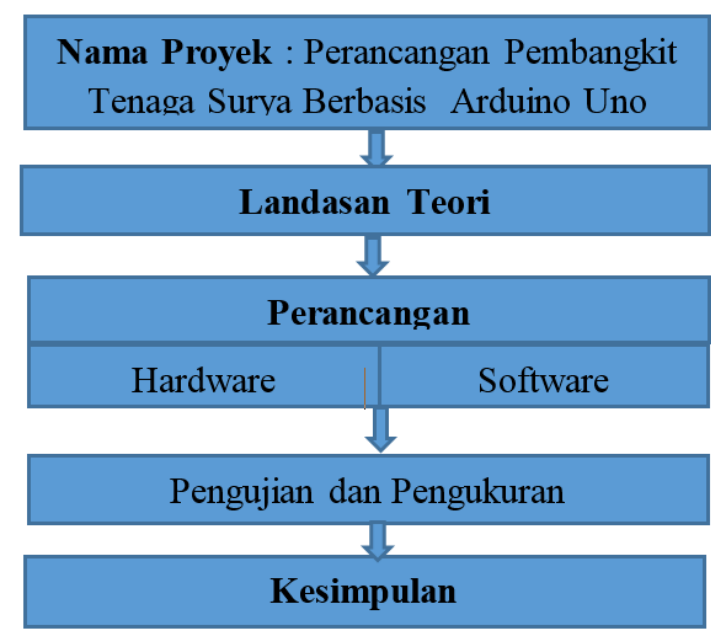

Gambar 3.1 Alir penelitian

\subsection{Perancangan Sistem}

Penelitian ini menggunakan diagram sebagai langkah awal untuk mempermudah pembuatan sistem. Diagram blok menggambarkan secara umum bagaimana cara kerja rangkaian secara keseluruhan. Diagram blok ini memiliki peran yang sangat penting mudah dalam pengambilan data dan menganilisa setiap subsistem yang telah dirancang.

Adapun diagram blok sistem ini digambarkan pada gambar 3.2. 


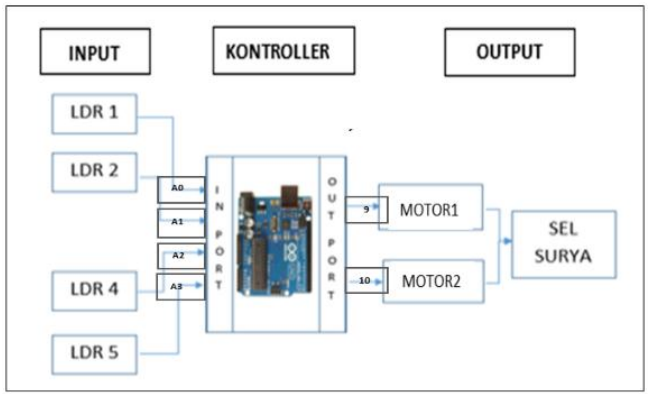

Gambar 3.2 Blok Perancangan sistem

\subsection{Perancangan Dan Inisiasi Sensor Input}

Sensor LDR ini akan menghasilkan perbedaan tahanan $0 \Omega$ hingga $1 \mathrm{M} \Omega$ ketika terpapar sinar matahari. Perbedaan tahanan dengan intensitas cahaya matahari tersebut menghasilkan perbedaan tegangan terhadap nilai referensi. Mekanik Holder Sensor LDR dirancang untuk bisa di pasang 5 buah sensor. Sensor LDR Timur Barat 2 unit; Sensor LDR Utara Selatan dan Sensor LDR target. Diposisikan sejajar dengan pergerekan sel surya seperti gambar 3.3

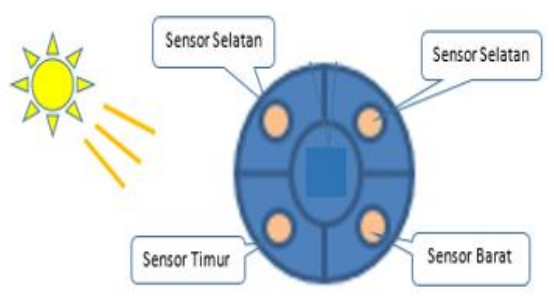

Gambar 3.3 Mekanik Holder Sensor LDR

\subsection{Perancangan Hardware}

Perancangan lengan robot yang akan diteliti mempunyai tiga derajat kebebasan.Penelitian ini juga melakukan pengukuran tegangan dan arus pada output power supply servo dari berbagai berat kotak yang dapat diangkat Lengan Robot dan besar sudut masing-masing motor servo memindahkan kotak dan tahap penyusunan kotak sesuai dengan warna kotak. Adapaun bentuk lengan robot yang direncanakan untuk rancang dan diteliti seperti pada gambar 3.4 dibawah ini.

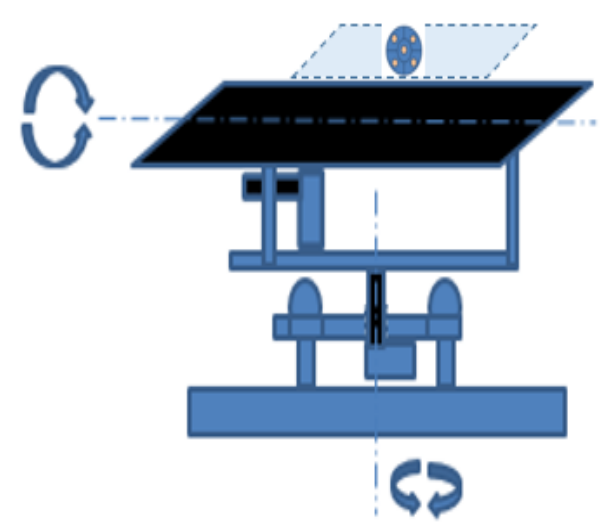

Gambar 3.4 Mekanik Pergerakan Sel Surya

\subsection{Perancangan Catu Daya}

Rangkaian catu daya memberikan supply tegangan pada alat pengendali. Rangkaian catu daya mendapatkan sumber dari tegangan PLN sebesar 220 VAC. Kemudian diturunkan transformator menjadi 12 VAC lalu tegangan AC tersebut diserahkan oleh dioda bridge menjadi tegangan DC. Keluaran dari dioda bridge ini kemudian masuk ke IC regulator yang fungsinya adalah untuk menstabilkan tegangan. IC regulator yang digunakan yaitu LM7805CT yang menghasilkan tegangan DC sebesar $+5 \mathrm{~V}$. Berikut ini adalah rangkaian catu daya $5 \mathrm{~V}$ pada sistem :

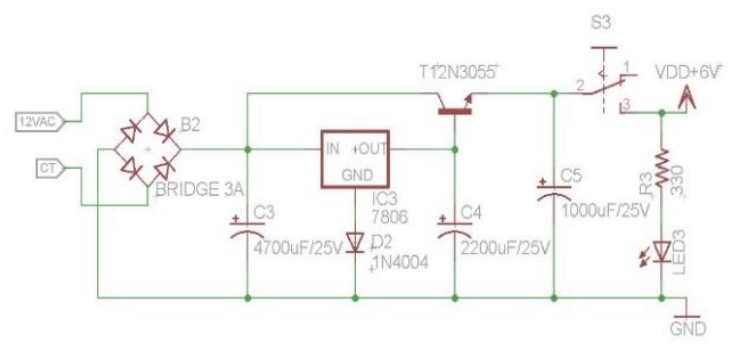

Gambar 3.5 Rangkaian Catu Daya Sistem 
November 2019

E-ISSN 2599-0616

P ISSN 2614-5979

Berikut ini adalah catu daya servo $6 \mathrm{~V}$ dengan $I C$ regulator $\mathrm{LM} 7806 \mathrm{CT}$ yang outputnya diberi transistor 2N3055 sebagai penguat arus sehingga menghasilkan output maksimum $3 \mathrm{~A}$.

\subsection{Perancangan Mikrokontroler Arduino Uno}

Pada perancangan menggunakan controller dengan susunan input, kontoller arduino uno dan hubungan ke output aktuator servo motor serta output sel surya sebagai berikut

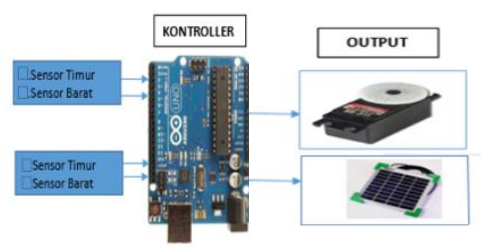

Gambar 3.6 Perancangan Hardware Kontroller Arduino

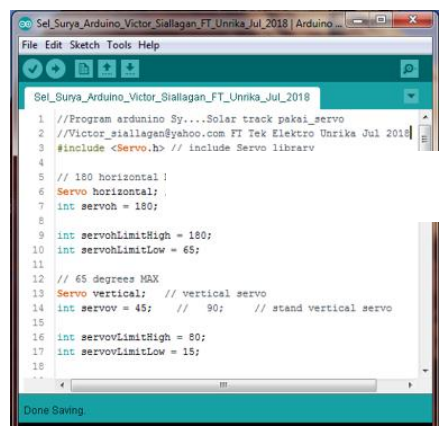

Gambar 3.7 Perangkat lunak Arduino

\subsection{Pengujian Alat}

Pengukuran dan pengujian dilakukan untuk membuktikan apakah rangkaian yang sudah dibuat bekerja sesuai dengan yang direncanakan. Pertama sekali pengujian dilakukan pada setiap bloknya dan pengujian beberapa blok yang saling berkaitan. Dalam setiap pengujian dilakukan dengan pengukuran yang nantinya akan digunakan untuk menganalisa dan membandingkan besaran daya pada saat sistem sel surya dengan sudut tetap diam terhadap sel surya beregerak dengan sensor dengan sensor pengarah ke sinar matahari.

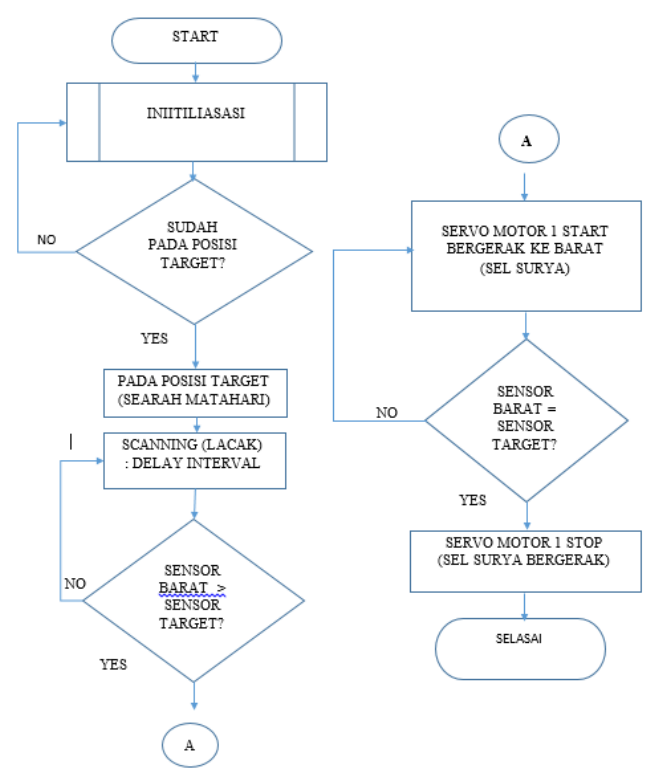

Gambar 3.8 Flowchart cara kerja sistem

\section{HASIL DAN PEMBAHASAN 4.1 Hasil Perancangan}

Sistem lengan robot dirancang berdasarkan blok diagram yang telah dibuat. Pada perancanagan ini semua komponen di ukur terlebih dahulu untuk memastikan komponen tersebut berfungsi dengan baik. Berikut adalah hasil perancangan robot lengan secara keseluruhan.

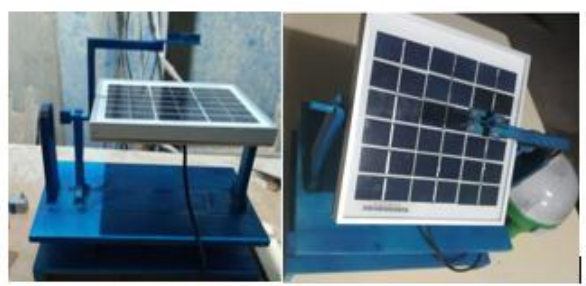

Gambar 4.1 Wujud Rancangan Pembangkit Listrik Tenaga Surya 


\subsection{Pengujian Sel Surya Posisi Tetap} Diam(fixed)

Pengujian tegangan arus dan daya keluaran pada saat sel surya dengan posisi tetap diam perlu dilakukan sebagai data referensi. Diperlukan untuk sebagai pembanding terhadap keluaran output sel surya dengan pengarah ke sinar matahari.

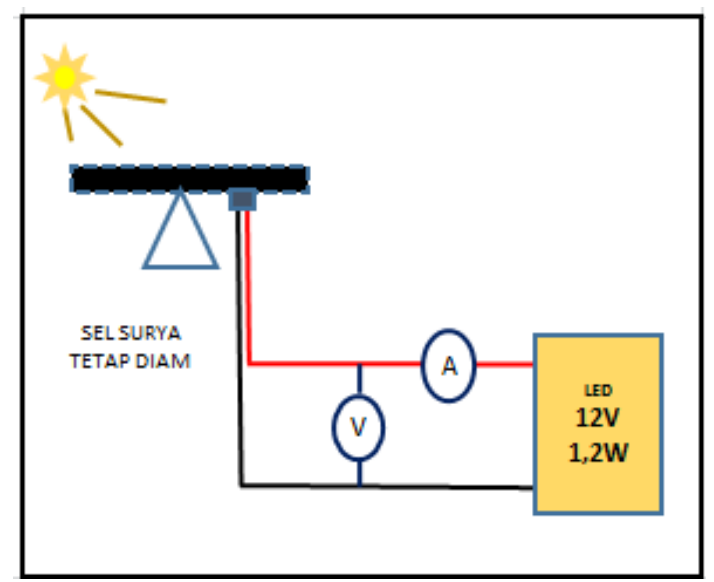

Gambar 4.2 Blok Pengujian Sel Surya Posisi Tetap Diam

\begin{tabular}{|c|c|c|c|c|c|}
\hline$S / N$ & JAM & $\begin{array}{l}\text { INTENSITAS CAHAYA } \\
\text { ( LUX) }\end{array}$ & $\begin{array}{c}\text { V } \\
\text { (Volt) }\end{array}$ & $\begin{array}{l}\text { Resistansi } \\
\text { (Ohm) }\end{array}$ & $\begin{array}{c}P \\
\text { (Watt) }\end{array}$ \\
\hline 1 & $6: 00$ & 211 & 7.2 & 4.1 & 0.03 \\
\hline 2 & $7: 00$ & 376 & 7.2 & 8.2 & 0.06 \\
\hline 3 & $8: 00$ & 558 & 7.2 & 13.1 & 0.09 \\
\hline 4 & 9:00 & 636 & 7.2 & 14.9 & 0.11 \\
\hline 5 & $10: 00$ & 984 & 7.2 & 24 & 0.17 \\
\hline 6 & $11: 00$ & 1030 & 7.2 & 25.3 & 0.18 \\
\hline 7 & $12: 00$ & 1250 & 7.2 & 29.4 & 0.21 \\
\hline 8 & $13: 00$ & 1280 & 7.3 & 60.2 & 0.44 \\
\hline 9 & $14: 00$ & 1400 & $\begin{array}{l}7.4 \\
\end{array}$ & 65 & 0.48 \\
\hline 10 & $15: 00$ & 1305 & 7.3 & $\begin{array}{ll}64.1 \\
\end{array}$ & 0.47 \\
\hline 11 & $16: 00$ & 1264 & 7.3 & 44.9 & 0.33 \\
\hline 12 & $17: 00$ & 1245 & 7.3 & 38.8 & 0.28 \\
\hline \multirow[t]{2}{*}{13} & 18:00 & 850 & 6.8 & $\begin{array}{l}12.4 \\
\end{array}$ & 0.08 \\
\hline & $\sum P$ & & & & 2.93 \\
\hline
\end{tabular}

Tabel 4.1 Hasil Pengujian Sel Surya PosisiTetap Diam

\subsection{Pengujian Sel Surya Otomatis Bergerak Dengan Sensor Pengarah}

Pengujian ini digunakan sistem pengarah cahaya matahari untuk mendapatkan sel surya selalu menghadap ke arah datangnya cahaya matahari

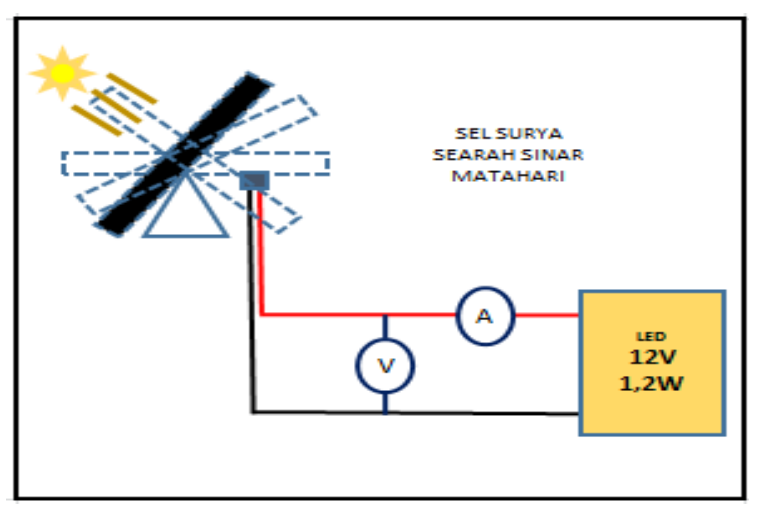

Gambar 4.3 Blok Pengujian Sel Surya Sistem Pengarah Sinar

Berikut ini adalah hasil pengukuran tegangan dan arus dengan sel surya

\begin{tabular}{|c|c|c|c|c|c|c|}
\hline S/N & JAM & $\begin{array}{c}\text { Pendekatan } \\
\text { INTENSITAS }\end{array}$ & $\begin{array}{c}\text { CAHAYA } \\
\text { (LUX) }\end{array}$ & V(Volt) & ( & $\begin{array}{c}P \\
\text { (Watt) }\end{array}$ \\
\hline 1 & $6: 00$ & $0^{\circ}$ & 224 & 7.1 & 2.8 & 0.02 \\
\hline 2 & $7: 00$ & $15^{\circ}$ & 392 & 7.1 & 4.9 & 0.03 \\
\hline 3 & $8: 00$ & $30^{\circ}$ & 605 & 7.2 & 12.3 & 0.09 \\
\hline 4 & $9: 00$ & $30^{\circ}$ & 660 & 7.2 & 13.8 & 0.10 \\
\hline 5 & $10: 00$ & $60^{\circ}$ & 1,096 & 7.2 & 25.1 & 0.18 \\
\hline 6 & $11: 00$ & $75^{\circ}$ & 1,315 & 7.3 & 34.2 & 0.25 \\
\hline 7 & $12: 00$ & $90^{\circ}$ & 1,543 & 7.3 & 40.4 & 0.29 \\
\hline 8 & $13: 00$ & $105^{\circ}$ & 1,550 & 7.4 & 85.7 & 0.63 \\
\hline 9 & $14: 00$ & $120^{\circ}$ & 1,580 & 7.5 & 110 & 0.83 \\
\hline 10 & $15: 00$ & $135^{\circ}$ & 1,398 & 7.6 & 91.9 & 0.70 \\
\hline 11 & $16: 00$ & $150^{\circ}$ & 1,380 & 7.5 & 85.35 & 0.64 \\
\hline 12 & $17: 00$ & $165^{\circ}$ & 1,342 & 7.4 & 67.6 & 0.50 \\
\hline 13 & $18: 00$ & $180^{\circ}$ & 895 & 6.8 & 26.2 & 0.18 \\
\hline & & $\Sigma P$ & & & & 4.44 \\
\cline { 5 - 8 } & & & & & & \\
\hline
\end{tabular}

otomatis bergerak dengan sensor pengarah seperti terlihat di tabel 4.2 
Tabel 4.2 Hasil Pengujian Sel Surya Sistem Pengarah Sinar

\subsection{Analisa}

Dari data pengujian sel surya system posisi tetap diam dan sel surya berpengarah sinar ke matahari diperoleh nilai daya yang berbeda. Berikut ini adalah hasil diagram karakteristik daya pada kedua pengujian.

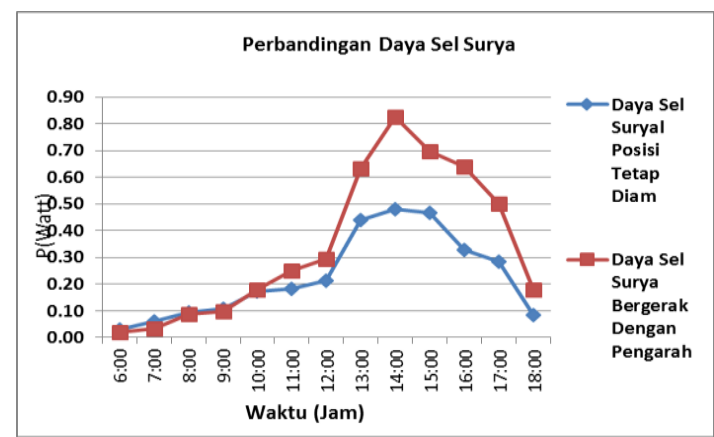

Gambar 4.4. Karakterisitik daya terhadap waktu

Dari gambar grafik diatas diperoleh daya sel surya paling besar di siang hari pukul 10:00 hingga 17:00 WIB atau ketika panas dan sinar matahari intensitasnya besar lebih besar dari 1000 Lux.

Perbedaan nilai daya yang dihasilkan sel surya dengan dua metoda ada fenomena. Pada saat pagi hari saat matahari terbit perbandingan dua sistem tidak ada perbedaan dikarenakan kondisi sinar pagi hari masih tertutup pegunungan/gedung tinggi sehingga sinar yang di dapat adalah pantulan dan hal yang sama juga ditemukan pada sore hari saat matahari terbenam.

Perbandingan keluaran sel surya posisi tetap diam 2,93 Watt dan rata-rata 0,24 Watt terhadap keluaran sel surya dengan pengarah sinar 4,44 Watt dan ratarata 0,34 Watt di dapati ada perbedaan.

Daya terukur yang dihasilkan sel surya paling besar 0,83 Watt; 7,5VDC 110 $\mathrm{mA}$ atau $0,1 \mathrm{~A}$ dimana spesifikasi sel surya 2,5 Watt; 8,2VDC; 0,3A dikarenakan kondisi beberapa hari cuaca tidak konsisten yaitu berubah-ubah kondisi hujan dan mendung.

Dari pengujian sel surya posisi tetap diam dan pengujian sel surya dengan pengarah dapat dicari peningkatan energi : Daya dengan pengarah sinar dikurangi daya posisi tetap diam diperbandingkan terhadap daya posisi tetap diam.

\section{KESIMPULAN DAN SARAN}

\subsection{Kesimpulan}

Berdasarkan hasil penelitian dan pembahasan dapat disimpulkan hal-hal sebagai berikut:

Rancangan sistem pembangkit tenaga surya dengan mengarahkan selalu searah tegak lurus dengan arah sinar matahari bias bekerja sesuai perancangan dan mendapatkan intensitas cahaya matahari lebih optimum dan menghasilkan energi listrik yang lebih besar dibanding dengan sel surya posisi tetap diam

\subsection{Saran}

Adapun saran dari penulis dari hasil perancangan yang telah dilakukan, untuk pengembangan selanjutnya alat ini, agar lebih maksimal disarankan:

Sistem ini perlu data analysis berbasis software supaya reprenstasi data dan penomena bisa dianalisa karena faktor cuaca banyak mengalami perubahan.

\section{DAFTAR PUSTAKA}

[1] Adhitya Noviardi, "Energi Alternatif Energi surya peluang bisnis baru”. http://industri.bisnis.com/read/2012 0306/44/67307/energi-alternatifenergi-surya-peluang-bisnis-baru. Diakses tanggal 12 Januari 2018 
November 2019

E-ISSN 2599-0616

P ISSN 2614-5979

[2] Budi Yuwono, Optimalisasi Panel Sel Surya Degan Menggunakan Sistem Pelacak Berbasis Sistem Mikrokontroller AT89C51, Skripsi, tidak diterbitkan, Universitas Diponegoro, Semarang.1995

[3] Cahyo Setyo Nugroho., Rahmat Adiprasetya., \& Rama Okta Wiyagi. Sistem Penjejak Matahari Dua Axis Pada Pembangkit Listrik Tenaga Surya, Jurnal, Tidak diterbitkan, Universitas Muhammadiyah, Yogyakarta, 2016

[4] Mona Berlian Sari., Yulkifli., \& Zulhendri Kamus. Sistem Pengukuran Intensitas dan Durasi Penyinaran Matahari Realtime PC berbasis LDR dan ,Motor Stepper, Jurnal, J.Oto.Ktrl.Inst (J.Auto.Ctrl.Inst), Vol 7(1), 2015,ISSN : 2085-2517, Universitas Negeri Padang, Padang, 2015

[5] Dickson Kho,Teknik Daya Elektronik.

https://teknikelektronika.com/wpcontent/uploads/2014/12/caramenghitung-dayalistrik.jpg?x22079.

Di akses tanggal 20 Februari 2018.

[6] Republik Indonesia. Peraturan Presiden Republik Indonesia Nomor 5 Tahun 2006, 2006. www.hukumonline.com. Di akses tanggal 20 Desember 2017

[7] Ted J Jansen, Solar Engineering Technology (Terjemahan Prof Wiranto Aris Munandar).New Jersey: Prentice Hall. (buku asli diterbitkan tahun 1995). 1995

[8] Subandi., Slamet Hani., Korelasi Suhu dan Instensitas Cahaya Terhadap Daya Solar Cell, Prosiding Seminar Nasional Aplikasi Sains \& Teknologi (SNAST) 2014, Yogyakarta, ISSN: 1979-911X. 15 November 2014

[9] Yudhi Wirantha Jaya Kusuma., Noer Soerjarwanto., Agus
Trisanto., Dikpride Despa.

Rancang Bangun Penggerak Otomatis Panel Surya Menggunakan Sensor Photodioda Berbasis Mikrokontroller Atmega 16 ,

ELECTRICIAN- Jurnal RekaysaTeknologi Elektro, Volume 9, No.1, 2015

[10] Oki Petrus Hutauruk., Takdir Tamba., \& Tua Raja Simbolon. Pembuatan Sistem Monitoring Optimasi Energi Cahaya Matahari Menggunakan Sensor Arus pada Antarmuka Personal Computer, Jurnal, Tidak diterbitkan, Universitas Sumatera Utara, 2016 